\title{
Mechanical Defenses in Leaves Eaten by Costa Rican Howling Monkeys (Alouatta palliata)
}

\author{
M.F. Teaford,${ }^{1 *}$ P.W. Lucas, ${ }^{2}$ P.S. Ungar, ${ }^{3}$ and K.E. Glander ${ }^{4}$ \\ ${ }^{1}$ Center for Functional Anatomy and Evolution, Johns Hopkins University School of Medicine, \\ Baltimore, Maryland 21205 \\ ${ }^{2}$ Department of Anatomy, George Washington University, Washington, DC 20052 \\ ${ }^{3}$ Department of Anthropology, University of Arkansas, Fayetteville, AR 72701 \\ ${ }^{4}$ Department of Biological Anthropology and Anatomy, Duke University, Durham, NC 27708
}

\section{KEY WORDS Alouatta; diet; fracture toughness; silica}

\begin{abstract}
Primate species often eat foods of different physical properties. This may have implications for tooth structure and wear in those species. The purpose of this study was to examine the mechanical defenses of leaves eaten by Alouatta palliata from different social groups at Hacienda La Pacifica in Costa Rica. Leaves were sampled from the home-ranges of groups living in different microhabitats. Specimens were collected during the wet and dry seasons from the same tree, same plant part, and same degree of development as those eaten by the monkeys. The toughness of over 300 leaves was estimated using a scissors test on a Darvell mechanical tester. Toughness values were compared between social groups, seasons, and locations on the leaves using ANOVA. Representative samples of leaves were also sun-dried for subsequent scanning electron microscopy and energy dispersive
\end{abstract}

Until recently, very little information has been reported from the field about the physical properties of foods that primates eat, though this could be an important factor in food selection and in understanding the form and wear resistance of the dentition (Lucas, 1979; Lucas and Peters, 2000; Lucas and Teaford, 1994; Strait, 1997; Yamashita, 1996). In the last decade or so, the situation has changed considerably, and recent work has shown that primate species often eat foods with different physical properties (Kinzey and Norconk, 1990, 1993; Strait, 1997; Yamashita, 1996). As the resources available to primates may vary significantly from one habitat to another (Teaford and Glander, 1996), food choice, and thus dental function, may also vary within species.

While fruits, flowers, leaves, and seeds vary in their relative importance in primate diets, leaves are easier to study mechanically because of their two-dimensional form. There are two major mechanical defenses in leaves. The first is their toughness, or the energy required to propagate a crack through them (Vincent, 1990, 1992). In thin, sheet-like foods such as leaves, toughness is the major factor obstructing the rapid rate of food breakdown in the mouth. For any two given foods (all other features of their loading in the mouth being similar), a tougher food will require higher forces to fracture (Wright and Vincent, 1996). The second mechanical defense is provided by silica in the leaf. Silica phytoliths are now known to be rather common in angiosperm leaves (Piperno, 1989). In the presence of particles hard enough to plastically indent (and thus scratch or pit) dental enamel, higher forces must be associated with x-ray (EDX) analyses in an attempt to locate silica on the leaves. Both forms of mechanical defense (toughness and silica) were found to be at work in the plants at La Pacifica. Fracture toughness varied significantly by location within single leaves, indicating that measures of fracture toughness must be standardized by location on food items. Monkeys made some food choices based on fracture toughness by avoiding the toughest parts of leaves and consuming the least tough portions. Intergroup and seasonal differences in the toughness of foods suggest that subtle differences in resource availability can have a significant impact on diet and feeding in Alouatta palliata. Intergroup differences in the incidence of silica on leaves raise the possibility of matching differences in the rates and patterns of tooth wear. Am J Phys Anthropol 129:99-104, 2006. @2005 Wiley-Liss, Inc.

higher wear rates (Lucas and Teaford, 1995). The cause of these scratches and pits could be either opaline (amorphous) phytoliths or extraneous siliceous grit (either quartz or a variety of aluminosilicates), since any of these is hard enough to indent enamel (Lucas and Teaford, 1995; Ungar et al., 1995).

We previously reported on canopy-level dust particles, with a mean minimum diameter ranging from $1.6 \mu \mathrm{m}$ in the wet season to $8.2 \mu \mathrm{m}$ in the dry season, and a rate of accumulation ranging from 12.5 particles per $\mathrm{mm}^{2}$ per day in the dry season to 117.0 particles per $\mathrm{mm}^{2}$ per day in the wet season (Ungar et al., 1995). Here we supplement this information with a survey of phytoliths in leaves (collected in the wet season) and measurements of toughness of leaves eaten by the howlers in both seasons.

Grant sponsor: NSF; Grant numbers: DBC 9118876; SBR 9601766; Grant sponsor: COSEN-PEW.

*Correspondence to: Mark F. Teaford, Center for Functional Anatomy and Evolution, Johns Hopkins University School of Medicine, 1830 E. Monument St., Room 303, Baltimore, MD 21205.

E-mail: mteaford@jhmi.edu

Received 19 April 2004; accepted 8 October 2004.

DOI 10.1002/ajpa.20225

Published online 31 August 2005 in Wiley InterScience (www.interscience.wiley.com). 


\section{Licania arborea (Chrysobalanaceae)}

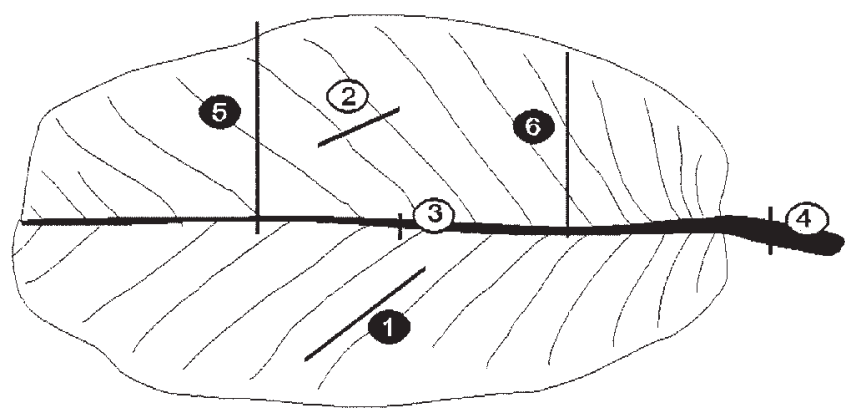

Fig. 1. Location of cuts 1-6 made on each leaf used in this study (analyses presented here are based on cuts 1,5 , and 6 , i.e., those highlighted in black).

More specifically, this study examines the physical properties of leaves eaten by Alouatta palliata from three different social groups at Hacienda La Pacifica in Costa Rica. The study area is a combination cattle ranch and rice farm of 1,990 ha, with pastures and fields broken by patches of dry forest serving as windbreaks (for further information on this site, see Teaford and Glander, 1996). The ranch is bounded by the Rios Corobici and Tenorio, each being lined by rich gallery forest. Mantled howlers are the only nonhuman primates on the ranch and are found in virtually all forest patches. The nonriver habitats show lower tree diversity than do the riverine habitats (Glander and Nisbett, 1996). Furthermore, the most plentiful trees in each habitat differ significantly, showing that resource availability varies between microhabitats. In this study, we tested the hypothesis that primates living in less diverse habitats would be forced to consume leaves that were better defended mechanically. This would have important consequences for dental function in animals that occupy different habitats.

\section{MATERIALS AND METHODS}

Although 42 howler social groups have been identified at La Pacifica, the analyses presented here focus on one nonriver group (known as group 1) and one river group (known as group 19). In the wet season, another nonriver group (group 2) was also included in the study (for group descriptions and locations, see Teaford and Glander, 1996). For each group, focal animals were followed throughout the day, and each of the different food items consumed was noted, including plant part and color (if applicable). Food items were collected whenever possible during the day to ensure that the samples analyzed were from the same tree, same plant part, and same degree of development as those eaten by the monkeys (e.g., young leaves vs. mature leaves).

This study focuses on the commonest leaves eaten by the study groups during July 1997 (at the height of the wet season) and February-March 1998 (at the height of the dry season). Unfortunately, during data collection, it quickly became apparent that many trees were missing their tree tags, and that some had also been previously misidentified. Thus, we cannot present species-by-species summaries of physical properties at this time, and our

\section{Gliricidia sepium (Fabaceae)}

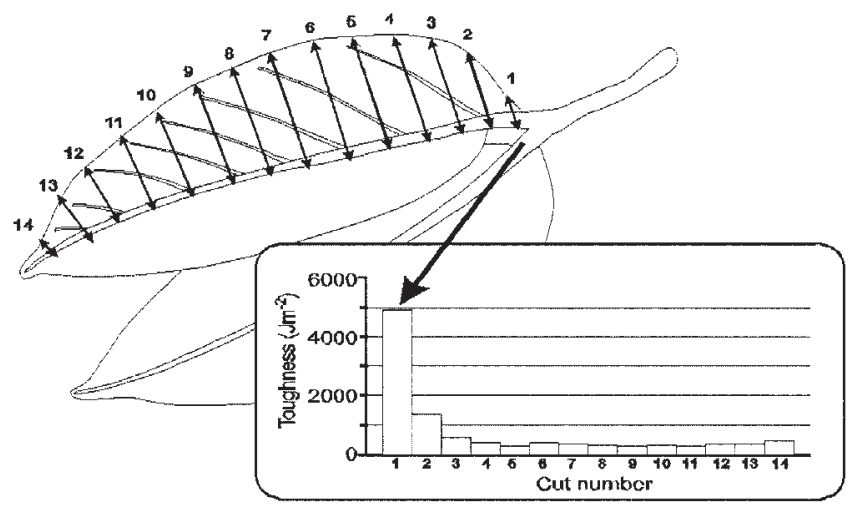

Fig. 2. Toughness map created using series of cuts parallel to cuts 5 and 6 .

selection of specimens was dictated solely by which ones the monkeys were eating. As a result, the plant samples probably include the same plant species from different home ranges. However, the number of specimens is a good indicator of the number of species tested within each social group.

Mechanical tests of leaves were made, within $24 \mathrm{hr}$ of collection, using a portable fracture toughness tester described by Darvell et al. (1996). The tester can be linked to a notebook computer, and it offers true forcedisplacement integration built into its hardware, allowing quick estimates of the toughness of food items (measured in Joules/meters squared). Though capable of running a variety of tests, those run here utilized the scissors-cutting test. Cut 1 is an attempt to define the "least tough path" within the lamina (Fig. 1), for which there is a lot of comparable information (Choong et al., 1992; Hill and Lucas, 1996; Lucas and Pereira, 1990). The major nutrients in a leaf are found in the mesophyll tissues (the palisade and spongy layers), which are best sampled by this cut (Choong, 1996). Cut 2 crosses secondary veins, cut 3 , the midrib, and cut 4 , the petiole (Fig. 1). These transport tissues contain much more fiber (i.e., cell wall) per unit volume than photosynthetic tissues (Lucas et al., 1995). Veins are often sheathed by cells called fibers, which is the anatomically correct term for the typical cells of angiosperm woody tissue. These possess 10 times the toughness of other cells of the same fiber content (Lucas et al., 1997, 2000), where "fiber" here refers to the nutritional usage of the term. The last two cuts, 5 and 6 , were made in an attempt to understand the apparent preference of some primates (including howlers) for leaf tips in terms of toughness selection. The procedure only involves two parallel cuts (Fig. 1). Thus, in order to establish whether some gradient might be found, a toughness map involving a series of cuts parallel to cuts 5 and 6 was made on one species (Gliricidia sepium) (Fig. 2).

Howlers at La Pacifica also eat some unexpanded leaves and associated shoots. These leaves were too small to examine by the systematic method described above. Instead, cuts were taken at key locations along the shoot, such as with guanacaste shoots (Enterolobium cyclocarpum) (Fig. 3).

Of the major cuts, results from cuts 1,5 , and 6 are reported here. Toughness estimates for these cuts were 


\section{Enteroloblum cyclocarpum (Fabaceae)}

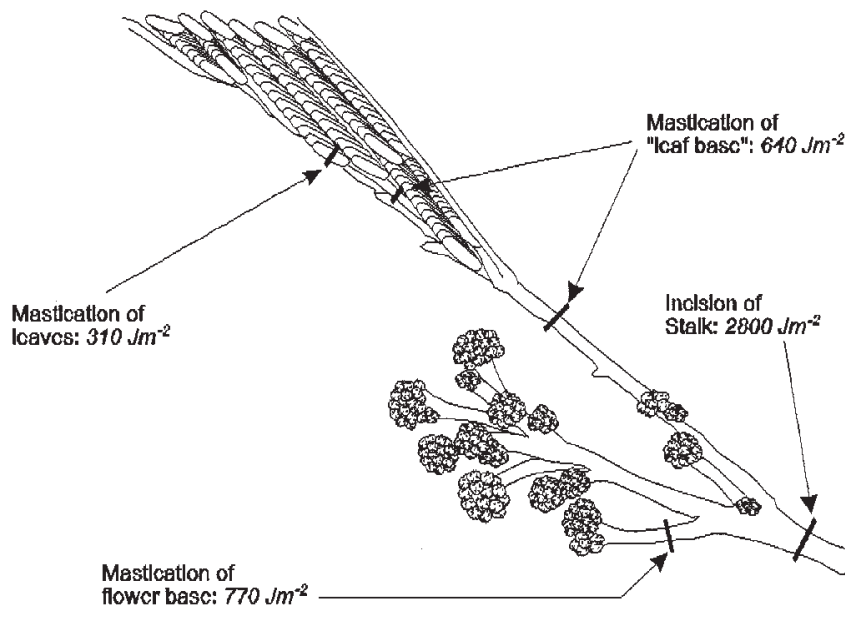

Fig. 3. Fracture toughness at various locations on food plant ("guanacaste") on which buds and unexpanded leaves could not be tested separately (based on photo in Lucas, 2004).

rank-transformed (Conover and Iman, 1981) and analyzed using analysis of variance (ANOVA) models. First, a three-way ANOVA was conducted on toughness values, with season, cut, and social group as the three factors. Because there was no higher-order interaction between the three factors, and none between cut and either group or season individually, the cut effect was first examined separately via single-factor ANOVA. In other words, toughness values for cuts 1,5 , and 6 were compared irrespective of season or group. Because of a significant interaction between season and group, differences between groups were considered separately for each season, and differences between seasons were considered separately for each group via two-factor ANOVAs. Bonferroni's tests were used to determine sources of significant variation in all cases.

In addition, leaves collected during the wet season were analyzed for phytoliths. Given the labor-intensive nature of the property-testing of leaves, and the smaller field crews available in the dry season (during the academic year), no leaves were analyzed for phytoliths during the dry season. Leaves were sun-dried in the field. Segments of about $1 \mathrm{~cm}$ in diameter were later cut out, carbon-coated, and viewed under a Cambridge scanning electron microscope equipped with an energy dispersive x-ray (EDX) elemental probe. All counts were made for 100 sec. Both the upper and lower epidermal layers were surveyed. When silicon was identified (present as an amorphous form of silica in plants), this was localized by switching to a finer-resolution probe (using a "spot size" of $20 \mathrm{~nm}$ ). The resulting spectra could only be analyzed qualitatively, because quantitative analysis requires stringent conditions concerning the geometry of the surface to be examined, which could not be met in this study. Thus data were scored as "present" or "absent." Specimens were either photographed with the carbon coating or additionally sputtered with gold-palladium and then photographed. The presence or absence of silica on leaves from groups 1 and 19 was then analyzed using a simple chi-square test.

\section{RESULTS}

\section{Intra-leaf differences in toughness}

One difference consistently underlaid all the results of this study: measures of toughness varied between locations on the leaves. Thus, measurements taken at the basal end of the leaf (cut 6) were significantly higher than those taken elsewhere on the leaf (cuts 1 or 5$)(P<$ $0.000, P<0.003$, respectively) (Tables $1-3$, Fig. 2 ). This difference appeared irrespective of the other factors considered in our analyses, e.g., season of collection or social group. In addition, we also noted that the attachment site of leaves was generally much tougher than the rest of the food consumed. This is shown very clearly with Gliricidia leaves (Fig. 2) and guanacaste shoots (Fig. 3), where it appears that there is a very rapid fall-off in toughness away from the attachment site.

\section{Seasonal variations in consumption of tough leaves}

During the dry season, leaf toughness data were only collected for the foods eaten by two social groups ( 1 and 19). Thus, seasonal differences could only be tested for those two groups. As leaf toughness and season of collection varied independently of cut (Table 2 ), there was no need to do separate analyses for each cut. Group 1 simply ate tougher leaves in the wet season than in the dry season, and group 19, by contrast, ate tougher leaves in the dry season than in the wet season (Tables 1 and 4).

\section{Intergroup differences in consumption of tough leaves}

Results indicate significant differences in the toughness of leaves eaten by different social groups as well. Because of a significant interaction between group and season (Table 2), leaf toughness values for groups were compared separately for the wet and dry seasons. Again, as leaf toughness and social group varied independently of cut, there was no need for separate analyses for each cut. Wet-season results show a significant difference between groups 1 and 2 (Tables 1 and 5), and dry-season results show a significant difference between groups 1 and $19(\mathrm{~F}=16.849, \mathrm{df}=1, P<0.000)$.

\section{Silica in leaves in the wet season}

About $40 \%$ of all leaves tested possessed silica, mostly associated with sharp-tipped trichomes (or hairs) projecting from the leaf surface (Fig. 4). Chi-square analyses indicated that leaves found in the home range of group 19 showed a significantly lower incidence of silica than did leaves from the home range of group 1 (Table 6).

\section{DISCUSSION \\ Intraleaf differences in toughness}

The pattern of development of toughness of tropical leaves was studied in detail for Castanopsis fissa (Fagaceae) leaves by Choong (1996, 1997). During development, the leaf base toughens more quickly than the leaf tip, presumably to protect the transport system of the leaf from predators. Rupture that introduces even a single air bubble into a major vein is terminal for all parts of the leaf that depend on that vein. In a mature C. fissa 
TABLE 1. Descriptive statistics for fracture toughness (Joules $/ \mathrm{m}^{2}$ )

\begin{tabular}{lccc}
\hline $\begin{array}{l}\text { Howler } \\
\text { social group }\end{array}$ & $\begin{array}{c}\text { Fracture toughness in wet } \\
\text { season (mean } \pm \mathrm{SE}) \\
\text { (no. specimens tested) }\end{array}$ & $\begin{array}{c}\text { Fracture toughness in dry } \\
\text { season (mean } \pm \mathrm{SE}) \\
(\text { no. specimens tested) }\end{array}$ \\
\hline Group 1 & 1 & $390 \pm 48(\mathrm{~N}=21)$ & $252 \pm 33(\mathrm{~N}=14)$ \\
& 5 & $500 \pm 66(\mathrm{~N}=27)$ & $319 \pm 54(\mathrm{~N}=17)$ \\
Group 2 & 6 & $771 \pm 99(\mathrm{~N}=25)$ & $565 \pm 151(\mathrm{~N}=17)$ \\
& 1 & $388 \pm 44(\mathrm{~N}=31)$ & $\mathrm{NA}$ \\
Group 19 & 5 & $363 \pm 47(\mathrm{~N}=29)$ & $\mathrm{NA}$ \\
& 6 & $446 \pm 55(\mathrm{~N}=29)$ & $346 \pm 42(\mathrm{~N}=14)$ \\
& 1 & $303 \pm 48(\mathrm{~N}=18)$ & $595 \pm 80(\mathrm{~N}=15)$ \\
& 5 & $442 \pm 64(\mathrm{~N}=21)$ & $868 \pm 145(\mathrm{~N}=15)$ \\
\hline
\end{tabular}

TABLE 2. Three-factor ANOVA of leaf toughness: overall ANOVA and tests for interactions between factors

\begin{tabular}{lll}
\hline Overall ANOVA & $\mathrm{F}=4.557(\mathrm{df}=14)$ & $P<0.000$ \\
\hline $\begin{array}{l}\text { Season, measurement, and } \\
\text { social group interaction }\end{array}$ & $\mathrm{F}=0.145(\mathrm{df}=4)$ & $P<0.965$ \\
$\begin{array}{l}\text { Season and measurement } \\
\text { interaction }\end{array}$ & $\mathrm{F}=0.712(\mathrm{df}=1)$ & $P<0.400$ \\
$\begin{array}{l}\text { Measurement and social group } \\
\text { interaction }\end{array}$ & $\mathrm{F}=1.775(\mathrm{df}=3)$ & $P<0.152$ \\
Season and social group interaction & $\mathrm{F}=17.477(\mathrm{df}=1)$ & $P<0.000$ \\
\hline
\end{tabular}

TABLE 3. Post hoc tests of differences in toughness between cuts: pairwise comparison probabilities ${ }^{1}$

\begin{tabular}{llll}
\hline & Cut 1 & Cut 5 & Cut 6 \\
\hline Cut 1 & 1.000 & & \\
Cut 5 & 0.217 & 1.000 & \\
Cut 6 & 0.000 & 0.003 & 1.000 \\
\hline
\end{tabular}

${ }^{1}$ One-way ANOVA: $\mathrm{F}=13.14(\mathrm{df}=2), P<0.000$.

TABLE 4. Results of ANOVA of differences in toughness between samples collected in different seasons

$\begin{array}{lll}\text { Social group } 1 & \mathrm{~F}=13.042(\mathrm{df}=1) & P<0.000 \\ \text { Social group } 19 & \mathrm{~F}=4.606(\mathrm{df}=1) & P<0.034\end{array}$

Social group $19 \quad \mathrm{~F}=4.606(\mathrm{df}=1) \quad P<0.034$

leaf, the midrib and secondary veins are tougher at their origin and at the margins of the leaf than elsewhere. Our data substantiate a major difference between the toughness of the leaf base and leaf tip in most leaves in our sample. In Gliricidia sepium, where we have a large sample ( $\mathrm{n}=94$ cuts), the basal third is typically about $30 \%$ tougher than the apical third of the mature leaf. Since toughness is produced by the behavior of cell walls (Lucas et al., 1995, 1997), the frequent selection of the apical part of leaves by the howlers at La Pacifica is basically selection against toughness and fiber content (Fig. 5). A lower-volume fraction of fiber (cell wall) in a leaf means a higher-volume fraction of cytoplasm (the protoplast) and thus greater nutritional value. Waterman and Kool (1994) showed that there can be a lower fiber content in leaf tips vs. leaf bases for some tropical leaves. Our results show that this is paralleled by toughness differences. Since fiber is colorless, tasteless, and odorless, the feeding cue for leaf-consumers is probably toughness (Choong et al., 1992; Hill and Lucas, 1996).

Add this difference to the apparent high toughness of attachment sites in general, and there are implications for howler dentitions as well. Howler incisors are used in a variety of ways. They may be used, as described above, to harvest leaf tips of minimal toughness. How-
TABLE 5. Post hoc tests of differences in toughness between samples collected in wet season from different social groups: pairwise comparison probabilities ${ }^{1}$

\begin{tabular}{lccc}
\hline & $\begin{array}{c}\text { Social } \\
\text { group 1 }\end{array}$ & $\begin{array}{c}\text { Social } \\
\text { group 2 }\end{array}$ & $\begin{array}{c}\text { Social } \\
\text { group 19 }\end{array}$ \\
\hline Social group 1 & 1.000 & & \\
Social group 2 & 0.015 & 1.000 & \\
Social group 19 & 0.299 & 1.000 & 1.000 \\
\hline
\end{tabular}

${ }^{1}$ One-way ANOVA: $\mathrm{F}=4.042(\mathrm{df}=2), P<0.019$.

ever, for some plants, they are used to detach whole leaves, or groups of leaves, from the tree. If the point of detachment always has high toughness (as suggested here), then incisal bite forces will have to be high. In contrast, the molars will act on the full range of tissues, which will require a load that is more frequently lower than that on the incisors due to the aforementioned drop-off in toughness away from the basal end of leaves. This may have implications for the relative wear rates of incisors vs. molars: the former often show far more wear than do the latter on the howlers at La Pacifica (personal observations).

\section{Seasonal and microhabitat variations in consumption of tough leaves}

From one perspective, the differences documented in this study might be a bit surprising. In other words, if the nonriverine habitats show less plant diversity (Glander and Nisbett, 1996), we might expect animals in those habitats, such as those in group 1 , to be forced to deal with a more limited series of options during the dry season and thus consume tougher leaves. However, the results show the opposite, with a riverine group (group 19) consuming tougher leaves in the dry season, and the nonriverine group (group 1) consuming tougher leaves in the wet season. These seasonal differences are mirrored by intergroup differences, with the riverine group (group 19) eating tougher leaves in the dry season than did the monkeys in the nonriverine group (group 1). This, how- 


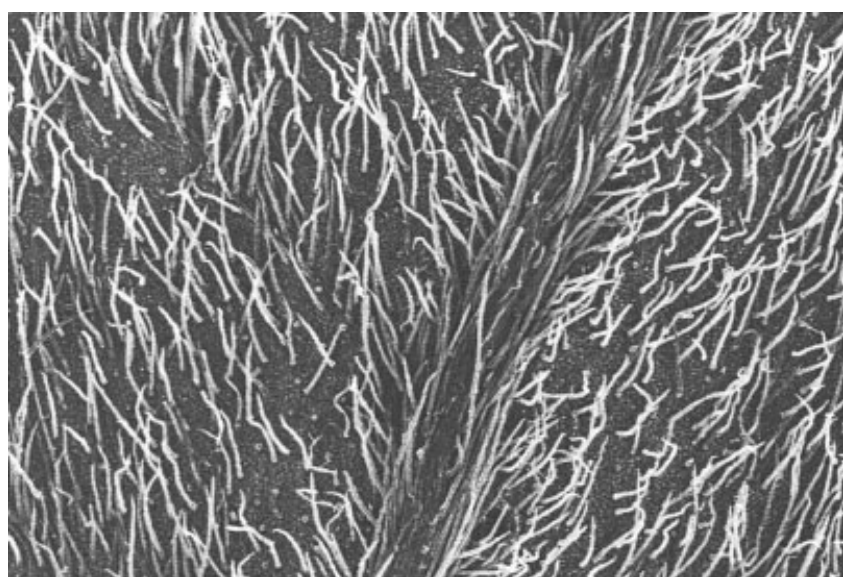

Fig. 4. SEM micrograph of long silica "trichomes" on leaf.

TABLE 6. Chi-square analyses of incidence of silica on leaves from groups 1 and $19^{1}$

\begin{tabular}{lccc}
\hline & With silica & Without silica & Row totals \\
\hline Social group 1 & 15 & 10 & 25 \\
Social group 19 & 3 & 10 & 13 \\
Column totals & 18 & 20 & 38 \\
\hline
\end{tabular}

${ }^{1}$ Chi-square $=4.68(P<0.05)$.

ever, may ultimately be due to seasonal differences in leaf growth in the riverine vs. nonriverine habitats. During the dry season, all food trees in the nonriverine forests drop their leaves. Thus, in the dry season, group 1 would have no choice but to eat immature leaves. By contrast, many of the trees in the riverine habitats retain their leaves during the dry season, due to a better supply of moisture near the river. Thus, during the dry season, group 19 would have choices unavailable to group 1, and animals in group 19 take more mature leaves in the dry season as a result. Why that would be so, nutritionally, remains to be seen.

\section{Silica in leaves in the wet season}

We previously showed the presence of large quantities of very fine grit particles in the canopy at La Pacifica (Ungar et al., 1995). The high incidence of silica on leaves eaten during the wet season offers another possible cause of dental microwear in the howlers. Interestingly, the higher incidence of silica on leaves from the nonriverine habitat correlates with a higher incidence of microwear features previously documented from nonriverine groups at La Pacifica (Teaford and Glander, 1996). Clearly, a comparison of the incidence of phytoliths on leaves eaten during the wet and dry seasons in different microhabitats is now necessary.

\section{CONCLUSIONS}

1. Fracture toughness varies significantly by location within single leaves, and therefore, measures of fracture toughness must be standardized by location on food items. Thus, discussions about the toughness of a whole leaf may be misleading.

2. Monkeys may apparently make food choices based on fracture toughness, in some cases avoiding the tough-

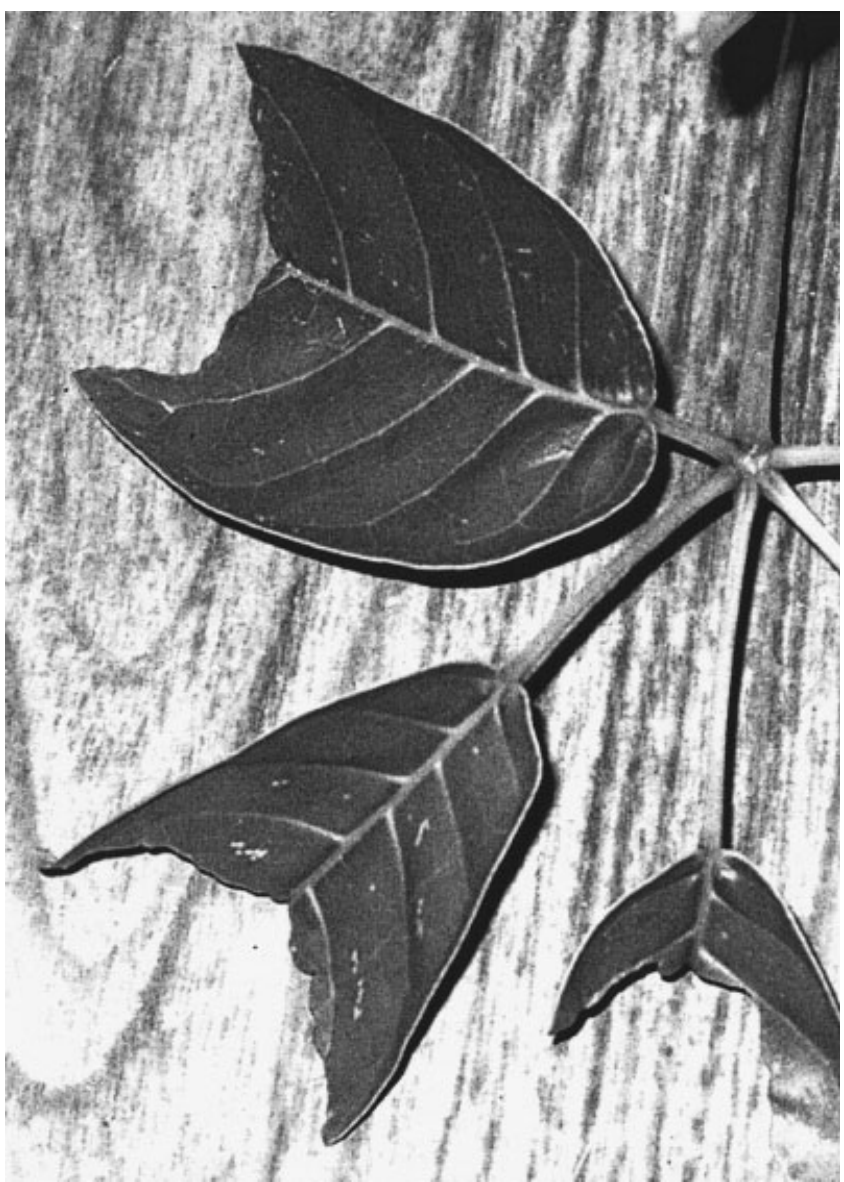

Fig. 5. Photograph of leaves showing typical pattern of apical damage due to howler feeding.

est parts of leaves (such as the base of the leaf) and only consuming the least tough portions (such as the leaf tip).

3. Two forms of mechanical defense (toughness and silica content) are evidently at work in the plants at La Pacifica. The relative importance of phytoliths vs. grit in causing tooth wear will require more work, including in vitro studies of the effects of these abrasives on teeth.

4. Group 1, a nonriver group, ate tougher leaves in the wet season than in the dry season, and group 19, a riverine group, ate tougher leaves in the dry season than in the wet season, reflecting seasonal differences in food availability between these microhabitats.

\section{ACKNOWLEDGMENTS}

This research was supported by NSF grant DBC 9118876 to M.F.T. and K.E.G., and SBR 9601766 to M.F.T., K.E.G., and P.S.U. Support was also received from COSEN-PEW grants for undergraduate students working on the howler project. For access and continued accommodation, we express our thanks to Dr. Stephan Schmidheiny and the management of Hacienda La Pacifica. For continued help and support in Costa Rica, we thank Werner and Lily Hagnauer, Tony and Vreni Leigh, and Margaret Clarke. For their comments and sugges- 
tions on the manuscript, we thank Clark Larsen and two anonymous reviewers.

\section{LITERATURE CITED}

Choong MF. 1996. What makes a leaf tough and how this affects the pattern of Castanopsis fissa leaf consumption by caterpillars. Funct Ecol 10:668-674.

Choong MF. 1997. Patterns of herbivory in tropical Fagaceae. Ph.D. thesis, University of Hong Kong.

Choong MF, Lucas PW, Ong JYS, Pereira BP, Tan HTW, Turner IM. 1992. Leaf fracture toughness and sclerophylly: their correlations and ecological implications. New Phytol 121:597-610.

Conover WJ, Iman RL. 1981. Rank transformations as a bridge between parametric and nonparametric statistics. Am Stat 35:124-129.

Darvell BW, Lee PKD, Yuen TDB, Lucas PW. 1996. A portable toughness tester for biological materials. Mes Sci Technol 7:954-962.

Glander KE, Nisbett RA. 1996. Community structure and species density in tropical forest associations in Guanacaste Province, Costa Rica. Brenesia45-46:113-142.

Hill DA, Lucas PW. 1996. Toughness and fiber content of major leaf foods of wild Japanese macaques (Macaca fuscata yakui) in Yakushima. Am J Primatol 38:221-231.

Kinzey WG, Norconk MA. 1990. Hardness as a basis of fruit choice in two sympatric primates. Am J Phys Anthropol 81:5-15.

Kinzey WG, Norconk MA. 1993. Physical and chemical properties of fruit and seeds eaten by Pithecia and Chiropotes in Surinam and Venezuela. Int J Primatol 14:207-226.

Lucas PW. 1979. The dental-dietary adaptations of mammals. N J Geol Paläont 8:486-512.

Lucas PW. 2004. Dental functional morphology. Cambridge: Cambridge University Press.

Lucas PW, Pereira BP. 1990. Estimation of the fracture toughness of leaves. Funct Ecol 4:235-236.

Lucas PW, Peters CR. 2000. Function of postcanine tooth crown shape in mammals. In: Teaford MF, Smith MM, Ferguson MWJ, editors. Development, function and evolution of teeth. Cambridge: Cambridge University Press. p 282-289.

Lucas PW, Teaford MF. 1994. Functional morphology of colobine teeth. In: Davies AG, Oates JF, editors. Colobine monkeys: their ecology, behaviour and evolution. Cambridge: Cambridge University Press. p 173-204.

Lucas PW, Teaford MF. 1995. Significance of silica in leaves eaten by long-tailed macaques (Macaca fascicularis). Folia Primatol (Basel) 64:30-36.

Lucas PW, Darvell BW, Lee PKD, Yuen TDB, Choong MF. 1995. The toughness of plant cell walls. Philos Trans R Soc Lond [Biol] 348:363-372.

Lucas PW, Tan HTW, Cheng PY. 1997. The toughness of secondary cell walls and woody tissue. Philos Trans R Soc Lond [Biol] 352:341-352.

Lucas PW, Turner IM, Dominy NJ, Yamashita N. 2000. Mechanical defences to herbivory. Ann Bot 86:913-920.

Piperno DR. 1989. The occurrence of phytoliths in the reproductive structures of selected tropical angiosperms and their significance in tropical paleoecology, paleoethnobotany and systematics. Rev Paleobot Palynol 61:147-173.

Strait SG. 1997. Tooth use and the physical properties of food. Evol Anthropol 5:199-211.

Teaford MF, Glander KE. 1996. Dental microwear and diet in a wild population of mantled howling monkeys (Alouatta palliata). In: Norconk MA, Rosenberger AL, Garber PA, editors. Adaptive radiations of neotropical primates. New York: Plenum Press. p 433-449.

Ungar PS, Teaford MF, Glander KE, Pastor RF. 1995. Dust accumulation in the canopy: a potential cause of dental microwear in primates. Am J Phys Anthropol 97:93-99.

Vincent JFV. 1990. The fracture properties of plants. Adv Bot Res 17:235-287.

Vincent JFV. 1992. Biomaterials. A practical approach. Oxford: IRL Press.

Waterman PG, Kool KM. 1994. Colobine food selection and plant chemistry. In: Davies AG, Oates JF, editors. Colobine monkeys: their ecology, behaviour and evolution. Cambridge: Cambridge University Press. p 251-284.

Wright W, Vincent JFV. 1996. Herbivory and the mechanics of fracture in plants. Biol Rev 71:401-413.

Yamashita N. 1996. Seasonal and site specificity of mechanical dietary patterns in two Malagasy lemur families (Lemuridae and Indriidae). Int J Primatol 17:355-387. 